\title{
The International Union of Forest Research Organizations (IUFRO) and Debates About Forest-Water Relations During the Late 19th Century
}

\author{
Christian Lotz \\ Herder Institute for Historical Research on East Central Europe, Germany
}

\begin{abstract}
Examining the International Union of Forest Research Organizations (IUFRO) and its research on forest-water relations, the article investigates the relation between scientific internationalism and national expertise. It juxtaposes existing arguments regarding the paradigmatic character of 19th century arguments about deforestations. In particular, in 1999, Christian Pfister and Daniel Brändli argued that, in Switzerland during the second half of the 19th century, forestry administrators forged an argument that deforestations in mountainous regions lead to floods in the valleys. As this argument helped to install new Swiss forest legislation in 1876, forbidding deforestations in the mountains, Pfister and Brändli called it a "deforestation paradigm". In contrast, sources of the IUFRO provide a different picture. At IUFRO meetings, i.e., at the international level of debate, no such paradigm existed. Instead, IUFRO participants discussed various conclusions that could be drawn from research on deforestations. Regarding the outcome of IUFRO projects, participants reported partly in opposing ways about the results of the research projects in forestry journals in their respective countries. Exploring these reports, the article provides an explanation for these different national representations of international research projects.
\end{abstract}

Keywords: international organizations, international congresses, forest ecology, deforestation paradigm, maps

\section{Introduction}

Between 4 and 11 September 1900, roughly 30 forestry experts came together in Switzerland for a meeting of the International Union of Forest Research Organizations (IUFRO) and to visit forest experimental stations in several Swiss mountainous regions. Among other features, they investigated the rain drain collecting apparatus that the Swiss forest research station had installed there. As the apparatus was a prototype, it is not surprising that the participants had lively discussions about the advantages and disadvantages of the technical features of the apparatus, as well as about the reliability of the data and the conclusions that could be drawn from them. ${ }^{1}$ Such debates are not surprising because differences about technical aspects and the reliability of data were (and are) basic elements of scientific debates. However, as this article will show, in different forestry journals, IUFRO participants reported partly in opposing ways about the results of the research projects. The article will investigate these reports about the IUFRO and explore why the representations of international research projects in national contexts are so different: What does this illustrate about the relation between

Christian Lotz, PD Dr., Herder Institute for Historical Research on East Central Europe, Germany.

1 Schwappach, Adam: Dritte Versammlung des internationalen Verbandes forstlicher Versuchsanstalten; in: Zeitschrift für Forst-und Jagdwesen 32 (1900) pp. 753-756. 
scientific internationalism and national expertise and, in this particular case, about the paradigmatic character of a deforestations paradigm?

In order to answer these questions, the article will first reflect on the historiography about forest-water research to date. Then, the article will outline its conceptual framework and its sources. In the main section, two examples of forest-water research will be studied in detail. The conclusion will provide some suggestions about worthwhile paths for further research.

A wide variety of studies on environmental history and the history of sciences have tackled the exploration of forest-water relations. As part of his work on "green imperialism", Richard Grove, for instance, analysed the efforts of 18th and early 19th century scientists to explore the impact of forests on climate. In particular, they tackled the relation of deforestation and a supposed or measured decrease in rainfall. When, during the 1840s and 1850s, a series of serious droughts hit British colonies in South Africa, the botanist, John Croumbie Brown, urged the government in London to take action. The devastating effects of the droughts were Brown's most powerful argument, allowing him "to threaten the state with God, death, time and money". 2 Although the government did not agree with this argument, the discourse about a relation between deforestation and a decrease in rainfall was obviously powerful enough to let the colonial administration install environmental measures in some of the areas in question. ${ }^{3}$

The research of John Croumbie Brown, which Grove describes in detail, is only one example in a variety of inquiries since the 18th century into the relation between vegetation and meteorology. Great names of natural sciences, such as Alexander von Humboldt or Jean-Baptiste Boussingault, are related with these issues. As Engelhard Weigl showed in 2004, the ideas and arguments about water-regimes lively circulated among a growing number of studies. ${ }^{4}$ In Europe, as well as in the colonial contexts of Asia, Africa, and South America, such studies focused on two main questions. First, whether or not the amount of rainfall is related to the extent of forest cover, i.e., if a given forest cover could prevent a region from droughts. Second, whether or not the forest cover, in particular in mountainous regions, can cause or prevent floods. In 1999, Christian Pfister and Daniel Brändli analysed the debates about forest-water relations in Switzerland. ${ }^{5}$ In a Swiss governmental commission of $1868 / 69$, participants saw heavy rainfall as the main reason for floods, while deforestation played a secondary role. However, in order to support the project of a new forest law that aimed at protecting forests in mountainous regions, forestry experts and the Swiss forestry society (Schweizerischer Forstverein) publicly stressed the argument that deforestations in the mountains cause floods in the valleys. Pfister and Brändli even use the term "deforestation paradigm" (Abholzungsparadigma) to describe the political power of such an argument in the late 19th century.

\footnotetext{
${ }^{2}$ Grove, Richard: Scottish Missionaries, evangelical discourses and the origins of conservation thinking in Southern Africa 1820-1900; in journal of Southern African Studies, 15 (1989), pp. 163-187, here 182.

3 Grove: Scottish Missionaries, pp. 183-186.

${ }^{4}$ Fedotova, Anastasia/ Loskutova, Marina: The studies over the impact of forests on climate and the rise of scientific forestry in Russia. From local knowledge and natural history to modern experiments in life sciences, 1840s - early 1890s; in: Kingsland, Sharon/ Phillip, Denise (ed.): Life Sciences, Agriculture and the Environment, New York 2014, pp. 113-137; Andréassian, Vazken: Waters and forests. From historical controversy to scientific debate; in: Journal of Hydrology 291 (2004) 1-2, pp. 1-27; Weigl, Engelhard: Wald und Klima. Ein Mythos aus dem 19. Jahrhundert; in: Humboldt im Netz-Internationale Zeitschrift für Humboldt-Studien, 9 (2004), pp. 80-99.

${ }^{5}$ Pfister, Christian/ Brändli, Daniel: Rodungen im Gebirge-Überschwemmungen im Vorland. Ein Deutungsmuster macht Karriere; in: Sieferle, Rolf Peter/ Breuninger, Helga (ed.): Natur-Bilder. Wahrnehmungen von Natur und Umwelt in der Geschichte. Frankfurt am Main/ New York 1999, pp. 297-324.
} 
Concerning international organizations, there is a wide variety of research on organizations that are devoted to natural sciences and resources. In particular, case studies about the International Council for the Exploration of the Sea (ICES), ${ }^{6}$ about the International Polar Years (IPY) ${ }^{7}$, as well as about several projects to establish international standardized maps of the world ${ }^{8}$, show the entanglement of scientific endeavours and political interest.

In order to examine the relation between scientific internationalism and national expertise, the article focusses on the IUFRO. The IUFRO was founded in 1891/92 as the "Internationaler Verband forstlicher Versuchsanstalten". It operated (and is still operating) as the main international organization regarding cross-border exchanges regarding forest science issues. In a broader perspective, the foundation of the IUFRO can be seen as one pathway in the international development of European forest sciences. ${ }^{9}$ In particular, the article will examine IUFRO meetings and how forestry experts debated forest-water issues during the late 19th century, as well as the kinds of representation depicting these forest-water issues in different national forestry journals.

As some sort of by-product, the article is able to provide a critical reflection on the history of the IUFRO itself. Existing historiography about the IUFRO lacks any reference to the tensions between international and national aspects of its work. Since the 1930s, several small texts have been published commemorating the IUFRO's foundation or briefly reviewing its history. ${ }^{10}$ These texts reinforce the story of the IUFRO as a harmonious scientific organization. ${ }^{11}$ On the contrary, the source material consulted while writing this article will shed light on one particular example, which shows how different research projects on forest ecology were represented in international and national contexts. ${ }^{12}$

Regarding the conceptual framework, the article takes up two features related to the history of international organizations, as well as the history of science. First, the article deals with the relation between what is understood in this context as "international" and "national". Rather than as opposites or in terms of a process evolving linearly from a national to an international framework of science, the "international" and the "national" distinctions came about during the 19th century in a complementary process: On the one hand, scientists saw their work and its results as making a contribution to the scientific power of their own nation; on the other hand, they stressed the "supranational qualities of science" and intensified international cooperation. ${ }^{13}$ Here, international organizations, as well as museums, exhibitions, international congresses, multinational

\footnotetext{
${ }^{6}$ Rozwadowski, Helen M.: The sea knows no boundaries. A century of marine science under ICES, Kopenhagen 2002.

7 Lüdecke, Cornelia: Das Erste Internationale Polarjahr (1882-1883) und die Gründung der Deutschen Meteorologischen Gesellschaft im Jahr 1883; in: Historisch-meereskundliches Jahrbuch (2002) 9, pp. 7-24.

${ }^{8}$ Pearson, A./ Taylor, D. R./ Kline, K. D./ Heffernan, M: Cartographic ideals and geopolitical realities: international maps of the world from the 1890s to the present; in: Canadian Geographer 50 (2006) 2, pp. 149-176.

9 Hölzl, Richard: Historicizing Sustainability: German Scientific Forestry in the Eighteenth and Nineteenth Centuries; in: Science as Culture, 24 (2010), pp. 431-460.

${ }^{10}$ Petrini, Sven: International cooperation in forestry; in: Svenska Skogsvårdsföreningens Tidskrift 36 (1938), pp. 1-28.

11 For example Richter, Albert/ Schwartz, Ekkehard: Zur Gründung des internationalen Verbandes forstlicher Versuchsanstalten in Eberswalde 1892; in: Archiv für Forstwesen 16 (1967) 6/9, pp. 557-561; Wudowenz, Rainer: 100 Jahre IUFRO [International Union of Forest Research Organizations]. Internationaler Verband Forstlicher Forschungsanstalten. Ausstellungen in der Alten Forstakademie Eberswalde, Eberswalde 1992.

12 This article seeks to contribute to the LOEWE-initiative "Regions of conflicts in Eastern Europe" that is run by the Herder Institute for Historical Research on East Central Europe and the Justus Liebig University Gießen (Germany), and that tackles the tensions between national and international approaches to ecological, political and social problems in history.

${ }^{13}$ Somsen, Geert J.: A History of Universalism. Conceptions of the Internationality of Science from the Enlightenment to the Cold War; in: Minerva 46 (2008), pp. 361-379, here p. 364.
} 
expeditions etc., are seen as arenas of "production and circulation of scientific and scholarly knowledge". ${ }^{14}$ Scientists presented their research projects and their results in these arenas. Exhibitions catalogues, display cases in museum and scholarly journals served as representations of science. The term "representation" is used here in the tradition of Michel Foucault. He introduced the term to characterize the relation between power and knowledge. Since Foucault introduced this term, it has proven to be a useful tool for an analysis of the development of modern science. "[R]epresenting certain facts or particular truths", as Cassidy, Lock, and Voss put it, "can influence how people understand the world, which in turn can influence how people act or perceive they are allowed to act". 15

Second, looking at processes of producing and circulating knowledge during the 19th century, there is a broad variety of studies dealing with "centres" and "peripheries" of science. Regarding forest sciences, it should not be surprising to observe the prominent position of German scientists in an international forestry organization by the end of the 19th century, as Germany was one of the strongholds of forest sciences at that time. ${ }^{16}$ However, it is not the goal of this article to identify a German centre of forest sciences, to this extent, nor to trace the representations of its forms of knowledge at different peripheries. Instead, the article follows the argument of Sujit Sivasundaram, which urges "the need to see beyond fixed centers and peripheries. Rather, each locality has the capacity to become central". ${ }^{17}$ While Sivasundaram looks at the global scale, this article will adopt his perspective on a regional scale, i.e., Central Europe. The special case of this article is not the large (geographical and cultural) distance between two regions, but the obvious closeness. Despite the closeness between German, Swiss, and Austrian forestry experts, and despite the usage of German as a common language within the IUFRO, there were forestry research projects undertaken by the IUFRO that revealed - as the main part of this article will show-highly differing representations in national forestry journals.

This article is based on source material of the IUFRO stored in Archives in Eberswalde and in Zurich, as well as from experts that are involved in forest-water research at forestry schools or universities. The material consists of correspondence, proposals, notes, statistics, and maps about the research projects, as well as reports that have been published in different forestry journals in Europe. These reports in forestry journals are of particular importance for the approach of this article.

The approach focuses on how participants presented the meetings and the work of IUFRO in forestry journals in their home countries. This sort of representation analysis is suggested here as a tool in order to examine the circulation of arguments between the international level of debate and the national or regional contexts of the IUFRO participants. This article focuses on forest-water research in Central Europe between 1873 to 1914 , as this was the core area and the first time period of research under the guidance of IUFRO.

\footnotetext{
${ }^{14}$ Ash, Mitchell G./ Surmann, Jan (eds.): The nationalization of Scientific Knowledge in Nineteenth-Century Central Europe. An Introduction; in: Ash, Mitchell G./ Surmann, Jan (eds.): The nationalization of Scientific Knowledge in the Habsburg Empire, 1848-1918, Basingstoke 2012, pp. 1-29, here 1.

${ }_{15}$ Angela Cassidy, Simon J. Lock \& Georgina Voss Sexual Nature? (Re)presenting Sexuality and Science in the Museum, Science as Culture, 25 (2016), pp. 214-238, here 217; Foucault, Michel: Discipline and Punish. The Birth of the Prison, London 1979 (fr.: Surveiller et punir, 1975); Foucault, Michel: Archaeology of Knowledge, London 2002 (fr.: L'archéologie du savoir, 1969).

${ }^{16}$ Hölzl, Richard: Der “deutsche Wald” als Objekt eines transnationalen Wissenstranfers? Forstreform in Deutschland im 18. und 19. Jahrhundert; online: www.perspectivia.net/content/publikationen/discussions/7-2012/hoelzl_wald [26 February 2016].

17 Sivasundaram, Sujit: Sciences and the Global. On Methods, Questions, and Theory; in: Isis 101 (2010), pp. 146-158.
} 


\section{Advancing Transnational Exchange: International Forestry Congresses and Differing Representations of 19th Century Research on Forest Ecology}

Transnational exchanges among scientists who devoted their work to forestry issues took an upward trend during the late 18th and early 19th century, when a growing number of forestry journals were published. Reviewing foreign books, publishing reports on forestry journeys, and expeditions abroad, as well as publishing translations of articles or even books from other languages, these forestry journals formed the backbone of the cross-border circulation of knowledge on forestry. ${ }^{18}$ Furthermore, a growing number of private or state run forestry schools, academies, and research stations, as well as institutes at universities, provided a platform for students coming from abroad in order to study forestry in theory and practice. By the mid- $19^{\text {th }}$ century, some German schools, in particular Tharandt, Eberswalde, Gießen, and Munich, as well as the French forestry academy in Nancy, became highly frequented centres of international exchange. ${ }^{19}$

Transnational exchange about forestry entered a new era in the 1870s. Starting in 1873 in Vienna, international forestry congresses offered a forum for presenting and discussing current affairs in forestry. ${ }^{20}$ Browsing the agendas of these congresses, questions of forest ecology were a continuous issue. Congress participants discussed the influence of forests on water, the effects of injurious insects, etc. Interestingly enough, the course, as well as the outcome of debates about forest ecology, changed over time and congress participants from various countries reported in different, partly even opposing, ways about the outcome of these debates. After the congress in Vienna 1873, for instance, many reports were published about the outcome of the congress. ${ }^{21}$ Interestingly enough, reports in forestry journals differed regarding the specific questions that the congress suggested to be tackled in further research projects. In Lesnoj Žurnal", one of the leading Russian journals, published in St. Petersburg, an unnamed author (probably Aleksej Sergeevič Ermolov) ${ }^{22}$ reported about the congressional debates about forestry ecology. He argued that the participants had agreed that most of the questions related to forest ecology had local character and did not require international cooperation in research; only meteorological questions should be tackled in international cooperation. ${ }^{23}$ Other reports, such as

18 Żabko-Potopowicz, Antoni: Wpływ zachodnioeuropejskiego piśmiennictwa i idei ekonomicznych na rozwój wczesnokapitalistycznego gospodarstwa leśnego w Królestwie Polskim; in: Studia z Dziejów Gospodarstwa Wiejskiego, 8 (1966), pp. 311-320; Hölzl, Richard: Der "deutsche Wald" als Objekt eines transnationalen Wissenstranfers? Forstreform in Deutschland im 18. und 19. Jahrhundert; online: www.perspectivia.net/content/publikationen/discussions/7-2012/hoelzl_wald [26 February 2016].

${ }^{19}$ For example Brzozowski, Stanisław: Studia rolnicze, leśne i weterynaryjne Polaków w Wiedniu od XVIII do XX w., Wrocław 1967; Fryjordet, Torgeir: Skogadministrasjonen i Norge gjennom tidene, vol. 2: Tiden etter 1857, Oslo 1962, pp. 105-107; Rackham, Oliver: Trees and Woodland in the British Landscape. The Complete History of Britain's Trees, Woods and Hedgerows, London 1990, p. 101.

${ }^{20}$ Lotz, Christian: Expanding the space for future resource management. Explorations of the timber frontier in Northern Europe and the rescaling of sustainability during the 19th century; in: Environment and History 21 (2015), pp. 257-279, here 264-268; Lotz, Christian: Nachhaltige Herausforderung. Internationale forstwissenschaftliche Kongresse und die Maßstäbe zukünftiger Ressourcennutzung, ca. 1870-1914; in: Turkowska, Justyna Aniceta/ Haslinger, Peter/ Schweiger, Alexandra (ed.): Wissen transnational. Funktionen - Praktiken - Repräsentationen. Marburg 2016, pp. 223-242.

${ }^{21}$ Chlumecky, Johann von: Stenographische Protokolle des ersten Internationalen Congresses der Land- und Forstwirthe (19. bis 24. September 1873) Wien 1874, pp. 219-222; Anonym: Verhandlungen des internationalen Kongresses der Land- und Forstwirthe in Wien; in: Allgemeine Forst- und Jagdzeitung 49 (1873), pp. 401-411; Mathieu, Auguste: Congrès International Agricole et Forestier de Vienne en 1873; in: Revue des eaux et forêts 12 (1873), pp. 413-420; Anonym [Aleksej Sergeevič Ermolov?]: Sel'skohozâjstvennyj i lesnoj kongres" v Vene po voprosu o lesnoj statistike; in: Lesnoj Žurnal 4" (1874), pp. 115-120; Riksarkiv Oslo, S-1600/ Dc/ D/ L2333, Norman: "Beretning om den i Wien i September 1873 afholdte Kongres af Land- og Forstmænd", Troms $\varnothing, 18$ March 1874

22 This article uses the ISO9 standard for transliteration of Cyrillic letters.

23 Anonym [Aleksej Sergeevič Ermolov?]: Sel'skohozâjstvennyj i lesnoj kongres" v Vene po voprosu o lesnoj statistike; in: Lesnoj Žurnal" 4 (1874), pp. 115-120, here 119. 
the Norwegian report by Johannes Normann or the French report by Auguste Mathieu in Revue des Eaux et Forêt, did not limit the outcome of the congress to meteorological questions. ${ }^{24}$ Instead, they reported that the congress urged for a permanent commission, which should coordinate further research regarding the relations between forests and rainfall, sources, floods, etc.

Two aspects are interesting here. First, the representations of the congress in forestry journals obviously differed to a certain extent regarding the outcome of the meeting. Second, while the reports in forestry journals about the congress in Vienna in 1873 mentioned the issues and problems that should be treated at further congresses, the official documentation about the following congresses did not mention any of these unsolved questions. Instead, official documentations about congresses and exhibitions in Paris 1878, in Edinburgh 1884 and again in Vienna 1890 read, in most parts, like harmonious conversations: participants presented the outcome of their research as clear results. ${ }^{25}$ The congress in Vienna in 1890, in particular, left no space for critical arguments concerning problems of forest-meteorology research. ${ }^{26}$

It is a difficult problem to find reasons for the fact that the official documentation about the international forestry congress in Vienna 1873 represented a meeting with lively debates, while official reports of later international forestry congresses show almost no disputes. Helen Rozwadowski suggests that, looking at the International Council for the Exploration of the Sea, participants of such international meetings wanted to present a harmonious image to the public in order to make sure that national governments would continue to support those international endeavours. ${ }^{27}$ Regarding forestry, there is obviously a second reason for the harmonious official documentations. The participants of the Vienna congress in 1890 came to the conclusion that cross-border cooperation in forest research would improve research conditions in particular because many projects in forestry require(d) very long time periods (due to the long time scale of tree growth) and often extensive areas. The participants decided to "outsource" debates and conflicts: Adam Schwappach, a professor at the Prussian Forestry Academy in Eberswalde, and Karl Schuberg, a professor of forestry in Karlsruhe, suggested setting up a commission consisting of the directors of forest research stations from different countries. $^{28}$ As a result, representatives of German, Swiss, and Austrian research stations met in 1891 in Badenweiler and agreed on a constitution for an international association. One year later, after having asked the governments in their respective countries for permission, they came together at the Prussian Forestry Academy in Eberswalde and founded the "Internationaler Verband Forstlicher Versuchsanstalten"/ "Association Internationale des Stations de Recherches Forestières" - the constitution was written in German and French; an

\footnotetext{
${ }^{24}$ Mathieu, Auguste: Congrès International Agricole et Forestier de Vienne en 1873; in: Revue des Eaux et Forêts 12 (1873), pp. 413-420, here p. 418. Riksarkiv Oslo, S-1600/ Dc/ D/ L2333, Norman: "Beretning om den i Wien i September 1873 afholdte Kongres af Land- og Forstmænd", Troms $\varnothing, 18$ March 1874.

${ }^{25}$ Congrès international de l'agriculture, 11-19 juin 1878, Paris 1879; Scottish Arboricultural Society: International Forestry Exhibition 1884. Official Catalogue, Edinburgh 1884; Proskowetz, Max von (ed.): Bericht über die Verhandlungen und Beschlüsse des internationalen land- und forstwirthschaftlichen Congresses/ Rapport sur les travaux et les résolutions du congrès international agricole et forestier, Wien 1890.

26 Anonym [probably Adolf von Liebenberg]: Der land- und forstwirthschaftliche Congress zu Wien 1890; in: Centralblatt für das gesammte Forstwesen 16 (1890) pp. 515-553, here 526-527, note, in particular, how participants refused to debate Jäger's question regarding the forest's impact on rivers.

${ }_{27}$ Rozwadowski, Helen M.: The sea knows no boundaries. A century of marine science under ICES, Kopenhagen 2002 , pp. $38-40$.

28 Anonym [probably Adolf von Liebenberg]: Der land- und forstwirthschaftliche Congress zu Wien 1890; in: Centralblatt für das gesammte Forstwesen 16 (1890) pp. 515-553, here p. 546, Karl Schuberg/ Karlsruhe suggested to set up a commission (einen "Ausschuß zu ernennen") that invites delegates from those countries which participate in forest experiments or which want to participate in experiments.
} 
English translation was not given in 1891/92. ${ }^{29}$ IUFRO met 1893 in Vienna, 1896 in Braunschweig, 1900 in Zurich, 1903 again in Vienna, 1906 in Stuttgart and 1910 in Bruxelles. In this period, i.e., before the First World War, IUFRO was dominated by German experts, while Switzerland and Austria were each represented in IUFRO by one research station, i.e., the Swiss station at the Polytechnikum (later Eidgenössische Technische Hochschule, ETH) in Zurich and the Austrian station at the Versuchsanstalt in Vienna-Mariabrunn. The Germans were present with delegates of at least eight stations, i.e., Eberswalde, Tharandt, Braunschweig, Gießen, Eisenach, Karlsruhe, Hohenheim/Tübingen, and Munich. Of cause, daily work and the aims of IUFRO had nothing to do with majorities or political decisions, as IUFRO was an association for scientific exchange. ${ }^{30}$ However, the Germans remarkably formed the agenda of research projects within IUFRO. Since around 1900, a growing number of experts from other (mostly European) countries entered IUFRO and brought in forestry knowledge of a tremendous scope of different regions from cold Subarctic to warm Mediterranean regions, from the rainy Atlantic coast to the dry continental climate zones of Eastern Europe.

Despite the fact that German-speaking experts had an enormous influence in IUFRO, the research projects of IUFRO were of different origin and were not initiated by German-speaking experts alone. Rather, the process of starting new projects within IUFRO worked bottom-up. Participants suggested topics for research and the experts that were interested could take up the issue in order to create a common research agenda on a specific topic. One of the main issues was the complex relations between forests and water. Experts from almost all of the participating forest research stations took part in investigating the aspects of water-related questions of forest ecology.

Realizing the complexity of the issue, the participants of the IUFRO in 1890 decided to begin with elaborating a working plan in order to sort out aspects of main interest. In general, the IUFRO participants focused on two research areas. First, the question of rainfall above wooded and non-wooded land and second, the question of water drainage after rainfall in wooded and non-wooded mountainous regions. The first question derived from the debates about keeping defined areas of woodland in order to maintain a balanced climatic situation. As mentioned in the introduction, this debate already had a long tradition including climate research in colonial forests in Africa, Asia, and South America. The second question referred to the ongoing controversies about the causes of floods. Since around 1800, a growing number of articles and books had suggested the argument that deforestation in mountainous areas caused an increase in number and intensity of floods in the valleys. ${ }^{31}$ Many participants of IUFRO had guided forest-water research since the beginning of their academic career and, when in 1891/92 IUFRO was founded, they were able to contribute their experiences from different regions in Europe and the world. At the IUFRO meeting in 1900, the participants evaluated forest-water research that had been carried out so far and decided to hand over the issue of rainfall on wooded and non-wooded lowlands to Anton Müttrich in Prussia, and the question of water drainage in mountainous areas to Arnold Engler in Switzerland.

\section{Taming Rain and Forests? Anton Müttrich's Pilot Schemes}

Anton Müttrich was born in 1833 and studied forestry in Eberswalde. Beginning in the 1870s, Müttrich

\footnotetext{
${ }^{29}$ Forest Acadenye Eberswalde (FAE). Nr. 279, fol. 39, Minutes of meeting, 17 August 1892; fol. 133, Huffel to Danckelmann, 2 March 1896.

${ }^{30}$ FAE, Nr. 279, fol. 17, Danckelmann to Judeich, 14 January 1892.

31 Pfister/ Brändli: Rodungen im Gebirge, pp. 303-305.
} 
had been guiding research on forest-water relations. ${ }^{32}$ Summarizing Müttrich's articles on forest-water issues that were published from the 1890s, he discussed three aspects: The political context of forest research, the distinction between wooded and non-wooded land, and the error rate of instruments.

Regarding the political context, Müttrich reflected the state of current research on rainfall issues. On the one hand, Müttrich argued that there were experts who saw a clear connection between deforestation and the decline in rainfall, while, on the other hand, experts in general denied that there was any connection at all. Müttrich saw the political importance of this issue deriving, in particular, from debates about forest laws. As an example, Müttrich referred to a commission of the Prussian Parliament (Abgeordnetenhaus) and its task to prepare a new forest law for Prussia. The commission, Müttrich examined, came to the conclusion that the lowering water level in Prussian rivers was a result of a decreasing rainfall caused by deforestation in the respective areas. Müttrich reported this statement of the commission but, at the same time, clearly highlighted that the commission's opinion was only one of many other arguments and opinions. ${ }^{33}$

The distinction between wooded and non-wooded land played a major role in Müttrich's study of 1903 . Müttrich had elaborated this text for the IUFRO meeting in Vienna, explaining that, by looking at the forests situated on Prussian territory, rather than looking at maps, their borders were often blurred. ${ }^{34}$ His argument was based on a pilot scheme that Müttrich had guided in several forests in the Prussian provinces of Brandenburg, Silesia, and Pomerania. Müttrich had realized that many forests had blurred borders or wide border zones. Often, a dense forest slowly transcended into a wooded land, with glades and land, which was partially used for agricultural purposes. In explaining his study, Müttrich clearly admitted that, given the blurred borders of many forests, it was, in many cases, "doubtful if a rain collecting station should be seen as a station inside the forests, at the edge of a forest, or outside a forest". 35

Müttrich's explanations regarding forests' blurred borders are remarkable for two reasons. First, Müttrich's reflections enable us to understand to what extent forestry experts made up their mind about the basis and preconditions of their research. Here, it is worth setting Müttrich's reflections in the broader context of environmental history. There are many studies exploring the conflicts between traditional forms of forests usages (such as pasture for livestock) and the attempt of forest sciences and forest administrators in many European countries to "modernize" forest resource management, i.e., to call for the clarification of the border between forests and agricultural land, as well as the so-called wastelands, to drive out traditional usages and to maximize the production of marketable timber, mainly for industrial purposes, both inland and for export. ${ }^{36}$ However, the results of these attempts are an issue of debate. In 1998, James C. Scott came up with the argument that the state applied an "abstracting, utilitarian logic" ${ }^{97}$ to the forests: state forest administrators clarified borders between wooded and non-wooded land, as well as transformed ecologically balanced woodlands into standardized forests with strict management plans. "What is distinctive of this kind of logic",

32 Müttrich, Anton: Beobachtungs-Ergebnisse der im Königreich Preussen und in den Reichslanden eingerichteten forstlich-meteorologischen Stationen, 2 vol., Berlin 1875/76.

${ }^{33}$ Müttrich, Anton: Über den Einfluß des Waldes auf die Größe der atmosphärischen Niederschläge; in: Zeitschrift für Forst- und Jagdwesen 24 (1892), pp. 27-42, here 28-30.

${ }_{34}$ Müttrich, Anton: Bericht über die Untersuchung der Einwirkung des Waldes auf die Menge der Niederschläge. Für die vierte Versammlung des internationalen Verbandes forstlicher Versuchsanstalten zu Mariabrunn 1903, Neudamm 1903, p. 10.

35 Müttrich: Bericht über die Untersuchung. p. 10.

${ }^{36}$ Hölzl: Umkämpfte Wälder, pp. 203-230; Radkau, Joachim: Zur angeblichen Energiekrise im 18. Jahrhundert. Revisionistische Betrachtungen über die Holznot; in: Vierteljahrsschrift für Sozial- und Wirtschaftsgeschichte 73 (1986), pp. 1-37.

37 Scott, James C.: Seeing like a state. How certain schemes to improve the human condition have failed, New Haven 1998 , p. 11. 
Scott argues, "is the narrowness of its field of vision, the degree of elaboration to which it can be subjected, and above all, as we shall see, the degree to which it allowed the state to impose that logic on the very reality that was observed.“38 Scott's argument received objections, for instance, from Joachim Radkau, who stressed that, among forestry experts during the 19th and 20th century, standardized, monocultural forests were not a common goal, but an issue of debate. In some German states, forestry administration did not introduce monocultural forests into practice. ${ }^{39}$ Beyond that, taking into account Müttrich's reflections on blurred borders, it is possible to put forward another objection about Scott's argument. Obviously, by the end of the 19th century, the state forest administration in Prussia had not succeeded in imposing a major feature of the standardizing logic, i.e., clear borders between wooded and non-wooded territory, on "reality" to a very high degree. Instead, Müttrich found many sections in all of the forests he had selected to be testing grounds with blurred borders.

The second remarkable aspect of Müttrich's reflections on blurred borders is the contrast between the written text and the visualization in maps. Müttrich drew six maps with a scale of 1:200,000 of all of the forests that he had selected as testing grounds. It is interesting to compare Müttrich's small scale maps with maps of larger scales, such as the standard 1:25,000 topographic maps. Aspects of generalization become obvious at first sight. Whenever cartographers produced small scale maps, generalization was necessary to a certain extent. Without generalization, a map would contain so much information that it would be impossible to use, to "read", and to understand the map. However, there is not just one way of generalizing a map, but several different ways. It is the cartographer or the editor of the map who decides what should be included in a map, what can or must be ignored, how to depict various spaces, objects, themes etc. Müttrich, for example, decided to use only one type of line for the border of the forests (see ill. no. 1, Regenmessfeld Landsberg). By contrast, it would have been possible, even on a simple black and white map, to use a continuous line (-) for relatively clear borders and a broken line (- - - - - - ) for blurred borders between wooded and non-wooded territory.

Ill. nos. 2, 3, 4 and 5, 6, 7 show two sections of the Regenmessfeld Landsberg on different maps. In order to apply methods of critical cartography to these kinds of sources, two other types of maps are used here as reference: the Übersichtskarte (general map), with the same scale as Müttrichs's maps (1:200,000), as well as the topografische Karte (topographic map), with a scale of 1:25,000, issued by the Preußische Landesaufnahme (Prussian land survey). It is important to stress that even if the 1:25,000 map is used as reference map here, it was, of course, also subject to generalization. Nonetheless, in this particular case, the 1:25,000 map is useful as a tool to compare different ways of depicting aspects of the natural environment.

The details of the 1:25,000 maps (ills. nos. 4 and 7) show the extent to which the character of the forest's "border" varied. In some parts, the forests had clear borders, but there were many other areas with slow transitions from the forest to a varied environment: small spots of wooded land were mixed with heath and bogs, agricultural land and settlements. Despite this situation, Müttrich chose a continuous line for all of the forest's different kinds of borders. Using such a cartographic style, Müttrich continued a powerful discourse that had been very common in the management of the natural environment since the 18th century. Attempting to "improve" land use, state authorities and private entrepreneurs used maps in their respective territories to get an

\footnotetext{
38 Scott, pp. 11-12.

39 Radkau, Joachim: Die Ära der Ökologie. Eine Weltgeschichte, München 2011, p. 40 in particular his footnote 15. Already in 2010, Richard Hölzl criticized Scotts thin empirical basis, see Hölzl, Richard: Historicizing Sustainability: German Scientific Forestry in the Eighteenth and Nineteenth Centuries; in: Science as Culture, 24 (2010), pp. 431-460, here p. 434.
} 
overview of their resources, such as forests, agricultural land, or mineral ores. ${ }^{40}$ These maps contained a particular tension: on the one hand, a small scale map was a useful tool to manage a large territory. On the other hand, these small scale maps fuelled the suggestion that the natural environment exhibited less variety than it actually had, because small scale maps necessarily had to reduce complexity through generalization. This tension was not a mere cartographic-theoretical issue, but had an enormous practical impact, as generalized, less complex small scale maps promoted ideas about possible "improvements" for resource exploitation, the development of infrastructures, etc.

As a result, there are two aspects that emerge from this map analysis. In his maps, Müttrich depicted clear forest borders, although there were many slow transitions from wooded to non-wooded land. Beyond that, there was an obvious contrast between Müttrich's maps and his text: in his text, as outlined above, he argued that it was hard to define whether a rain collecting station should be regarded as being located "inside the forest, at the edge of a forest or outside a forest" ${ }^{41}$. Here, Müttrich admitted that in many areas, a clear border of the respective forest did not exist. On the contrary, he used continuous lines and suggested clear forest borders in his maps. In this regard, Müttrich's report of 1903 is not only an important source for understanding research on forest-water-relations within the IUFRO. It is also a remarkable example of the fact that it was possible for one author, Anton Müttrich, to present two "different images" of the natural environment at the same time, i.e., in one publication: a clear distinction between forests and the surrounding areas, and the blurred border zones between them. ${ }^{42}$

Finally, Müttrich reflected about the error rate of instruments. Müttrich used a rain gauge "Hellmann 86". This was named after Gustav Hellmann, a German meteorologist who had been testing instruments for measuring rainfall since the 1870s. Basically, rain gauges were simple instruments. They consisted of a container that was able to collect the falling rain. In 1886, Hellmann presented a rain gauge that had proven the most reliable results. The rain gauge "Hellmann 86 " was a cylindrical container that was covered by a funnel with an opening on top of standardized $200 \mathrm{~cm}^{2}$ in order to collect rain drops of this standardized area and to prevent evaporation as much as possible. ${ }^{43}$

\footnotetext{
${ }^{40}$ Hölzl, Richard: Historicizing Sustainability: German Scientific Forestry in the Eighteenth and Nineteenth Centuries; in: Science as Culture, 24 (2010), pp. 431-460, here p. 436; Laak, Dirk van: Planung. Geschichte und Gegenwart des Vorgriffs auf die Zukunft; in: Geschichte und Gesellschaft 34 (2008), pp. 305-326, here 322-324; see for example: Hartig, Georg Ludwig: Anweisung zur Taxation und Beschreibung der Forste, 2., ganz umgearbeitete und stark vermehrte Auflage, Gießen/ Darmstadt 1804, p. 20; Administrativ-statistischer Atlas vom Preussischen Staate, Berlin 1827/28 [Reprint with an introduction by Wolfgang Scharfe, Berlin 1990], map 9: "Bergwerks, Hütten- und Salinenverwaltung"; map 15: "Sprachen"; as well as Andree, Richard: Allgemeiner Handatlas, Bielefeld/Leipzig 1890, map 13 "Völkerkarte von Europa".

${ }^{41}$ Müttrich, Anton: Bericht über die Untersuchung der Einwirkung des Waldes auf die Menge der Niederschläge. Für die vierte Versammlung des internationalen Verbandes forstlicher Versuchsanstalten zu Mariabrunn 1903, Neudamm 1903 , p. 10.

42 Jutta Faehndrich and Sophie Perthus pointed at the aspect of "different images of the same region" that one author (the cartographer Charles William Meredith van de Velde) produced in his texts, maps and pictures of the Holy Land during the 19th century; see: Faehndrich, Jutta/ Perthus, Sophie: Visualizing the map-making process. Studying 19th century Holy Land cartography with MapAnalyst; in: e-Perimetron 8 (2013) 2, S. 60-84, here 61.

${ }^{43}$ Strangeways, Ian: A History of raingauges, in: Weather 65 (2010) 11, pp. 133-138.
} 


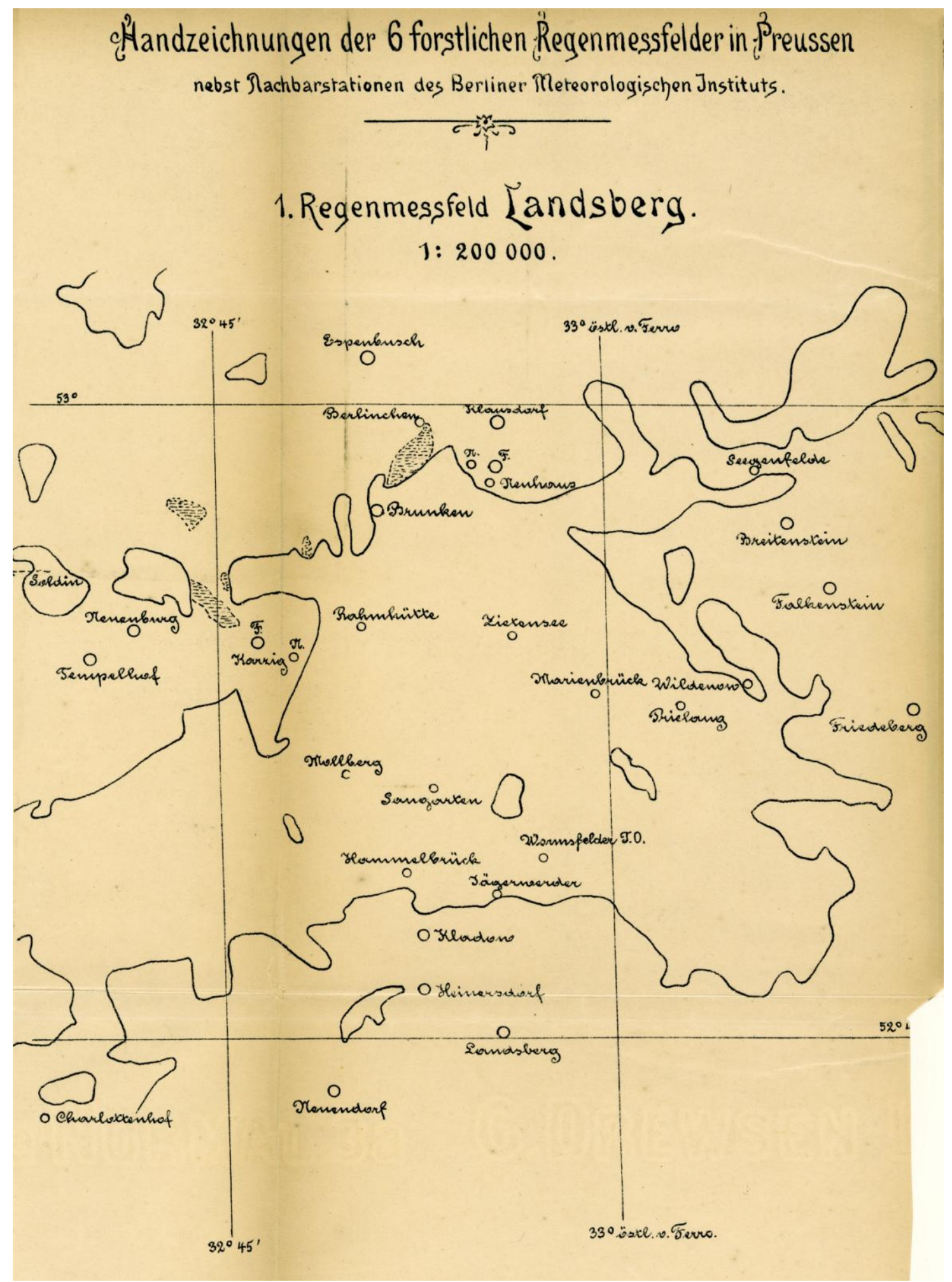

Illustration 1, Regenmessfeld Landsberg, 1:200,000, in: Müttrich, Anton: Bericht über die Untersuchung der Einwirkung des Waldes auf die Menge der Niederschläge. Für die vierte Versammlung des internationalen Verbandes forstlicher Versuchsanstalten zu Mariabrunn 1903. Original size: $32 \times 45 \mathrm{~cm}$. Source: Library of the Martin Luther University Halle-Wittenberg/Germany. 

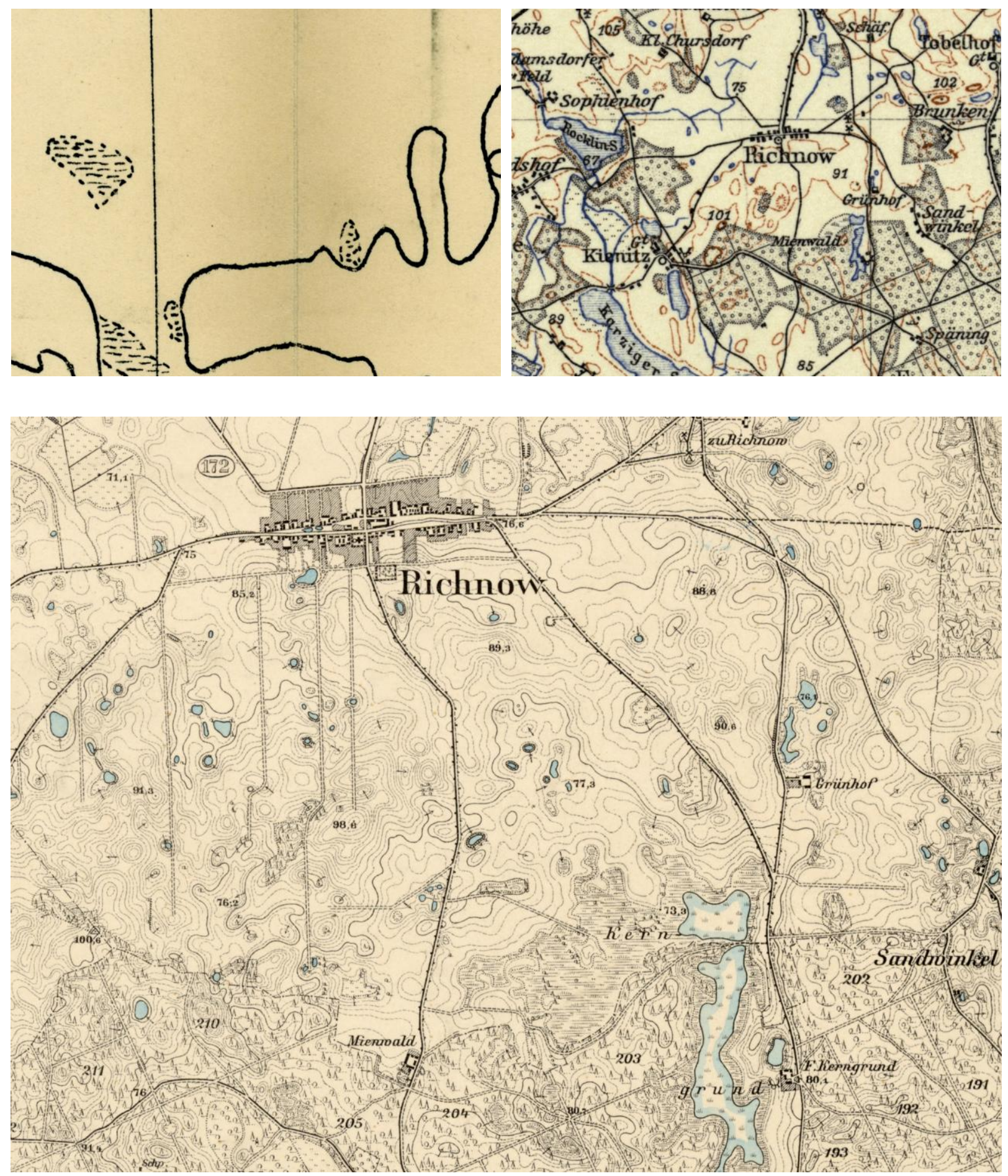

Illustration 2, top left: Detail of map Regenmessfeld Landsberg 1:200,000 by Anton Müttrich, 1903, showing forest border near Kartzig and Richnow (original size); Ill. 3, top right: Detail of Preußische Landesaufnahme: Topographische Übersichtskarte des Deutschen Reiches, scale 1:200,000, sheet 78, Cüstrin, Berlin 1902 (1919) (original size); ill. 4, bottom: Detail of Preußische Landesaufnahme: Topographische Karte, scale 1:25,000, sheet 1562 Karzig, Berlin 1890 (1891) (original size). Sources: Herder Institute Map Collection and Library of the Martin Luther University Halle-Wittenberg/Germany. 

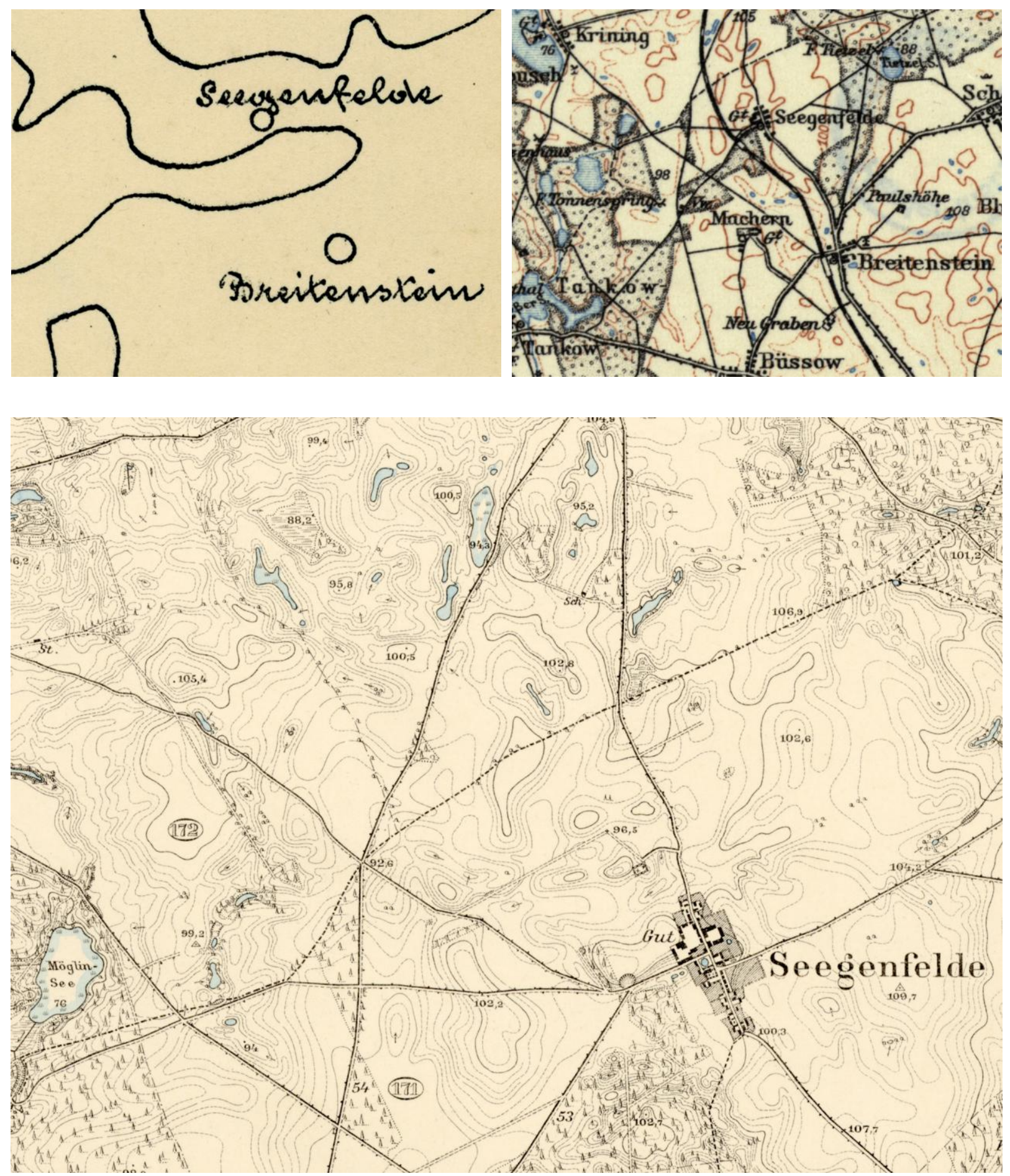

Illustration 5, top left: Detail of map Regenmessfeld Landsberg 1:200,000 by Anton Müttrich, 1903, showing forest border near Seegenflede (original size); ill. 6, top right: Detail of Preußische Landesaufnahme: Topographische Übersichtskarte des Deutschen Reiches, scale 1:200,000, sheet 79 Schwerin an der Warthe, Berlin 1902 (1924) (original size); ill. 7, bottom: Detail of Preußische Landesaufnahme: Topographische Karte, scale 1:25,000, sheet 1564 Büssow, Berlin 1891 (1893) (original size). Sources: Herder Institute Map Collection and Library of the Martin Luther University Halle-Wittenberg/Germany. 
Despite these tested technical features and efforts in standardization, Müttrich faced the same problems in measuring the rainfall that had been troubling meteorologists for decades, in particular the effects of wind on the rain gauge, as well as the reliability of the data collected. Regarding reliability, Müttrich was sceptical of a large number of staff members who, in part, had obviously not completely understood the instructions for handling the rain goauge. Furthermore, Müttrich realized that the rainfall, in general, varied during the years of study, resulting in big differences in the overall amount of rainfall year by year. As a result, Müttrich presented figures and preliminary results of his pilot schemes but, at the same time, he urged for the time periods of research to be enlarged so that he could compare a greater amount of results. ${ }^{44}$ Browsing through forestry journals in Europe at the end of the 19th century, research on forests and rainfall was a continuous issue. ${ }^{45}$ However, compared to the following example of studies about rain drain, Müttrich's work did not provoke such a variety of interpretations in forestry journals. In the conclusion, this article will come back to these questions of interpretation and will suggest some reasons for it.

\section{Tracking Rain Drain and Forging Arguments: Swiss Research and International Varieties of Data Interpretation}

Regarding the forest cover of mountains and the probability of floods, the research stations of Switzerland and Austria took the lead in preparing a working programme and guiding research. In 1890, the forest research station in Zurich had set up installations to measure the drainage of rainwater. The head of Switzerland's research station, Arnold Engler, his assistant, Philipp Flury, and their colleagues chose mountains in the canton of Bern (Emmental), comprising areas covered with forests and areas of bare rocks or grass vegetation. Engler tested several types of installations and instruments. In general, these installations consisted of large barriers that were able to guide the draining water on the surface to a point where the amount of water was measured. ${ }^{46}$ Reflecting the reliability of the instruments, Engler reasoned about the differences between the results that men read from the instrument's scale and results that machines could record. ${ }^{47}$ Here, again, the overall amount of rainfall year by year differed enormously, which led Engler to urge for further research.

Regarding Engler's research, it is particularly interesting to shift the perspective and to analyse how authors presented the outcome of this project and the work of IUFRO in different forestry journals. It is also striking to see how they reflected on the impact that such projects might have on further research, as well as on environmental policy in their respective countries. Due to the strong position of the German-speaking participants in IUFRO, the most detailed reports about IUFRO's work were published in German, Austrian, and Swiss journals. However, journals from other parts of Europe also reported about IUFRO.

Browsing through a variety of forestry journals, the representations of the Swiss rain drain project differ to

\footnotetext{
44 Müttrich, Anton: Bericht über die Untersuchung der Einwirkung des Waldes auf die Menge der Niederschläge. Für die vierte Versammlung des internationalen Verbandes forstlicher Versuchsanstalten zu Mariabrunn 1903, Neudamm 1903, p. 17.

${ }^{45}$ For example Demontzey, Prosper: La correction des torrents et le reboisement des montagnes (Rapport présenté au Congrès de l'Exposition internationale de Vienne); in: Revue des eaux et forêts 29 (1890), pp. 485-502; Romer, Eugeniusz: Wpływ lasów na wody gruntowe i odpływ wód w rzekach; in: Sylwan 19 (1901), pp. 181-194.

${ }^{46}$ Flury, Philipp: Die V. Versammlung des Internationalen Verbandes forstlicher Versuchsanstalten in Württemberg vom 8.-16. September 1906; in: Schweizerische Zeitschrift für Forstwesen, 58 (1907), pp. 25-27.

47 Schwappach, Adam: Dritte Versammlung des internationalen Verbandes forstlicher Versuchsanstalten; in: Zeitschrift für Forstund Jagdwesen 32 (1900), pp. 753-756.
} 
a remarkable extent: The Bulletin de la Société centrale forestière de Belgique printed just a short note about the IUFRO meeting in 1906, where Engler had shown the outcome of research in the Swiss mountains without mentioning the results. ${ }^{48}$ The Norwegian forestry expert Albert Karsten Myhrvold reported the exchange between research stations, but did not go into details. ${ }^{49}$ Philipp Flury of the Swiss station reported in Schweizerische Zeitschrift für Forstwesen and no wonder, followed the argumentation that Engler had presented at the meeting. Consequently, the readers of this Swiss journal read that the outcome of Engler's project allowed for a clear conclusion, i.e., "during the period of heavy rain drain, the forest delivers 30-50\% less water drainage at the surface than bare or meadow terrain.",50

On the contrary, Adam Schwappach, a professor at the Prussian forestry academy in Eberswalde, reported about the Swiss project rather reluctantly in the Zeitschrift für Forst- und Jagdwesen: "Cautiously, Engler refused to draw proven conclusions (sichere Folgerungen) from the observations". This is because Engler had to adopt the methods of observation several times and there had not yet been any extreme heavy rainfall (extrem starke Niederschläge) in the period of observation. Schwappach summed Engler's presentation up by saying that "probably (wahrscheinlich) the speed of drainage (Abflußgeschwindigkeit) on wooded terrain is 30-50\% lower than on non-wooded terrain". In his report to the Prussian Minister of Agriculture, Schwappach stressed in a similar way that Engler did not yet want to draw conclusions from the observations. ${ }^{51}$

Gabriel Janka delivered an article about the IUFRO meeting where Engler had presented his project to the Austrian Centralblatt für das Gesamte Forstwesen, and he went even further. He reported Engler's opinion that the experiments regarding water drainage "can for long not be seen as complete (können noch lange nicht als vollkommen angesehen werden)". Moreover, Janka quoted Engler's doubts "that it is almost impossible to indisputably ascertain (einwandfrei feststellen) the impact of forests on the water regime."

The examination of Müttrich's research on rainfall and Engler's on rain drain, as well as an analysis of the representations of these projects in forestry journals in Europe, provoke a couple of questions: Why was there such a contrast between the variety of interpretations of Engler's research, on the one hand, and Müttrich's project, on the other hand, that received no critical reaction? What were the reasons for the opposing representations of Engler's research on rain drain? It would be a misleading argument to point at a possible differing scientific authority of the Prussian Anton Müttrich, and of the Swiss Arnold Engler. This is because both were widely accepted experts and their work was highly appreciated in the IUFRO and beyond. ${ }^{53}$ More likely, the different ways of argumentation and context in Müttrich's and in Engler's reports led to different representations. In his report, Müttrich extensively wrote about various possible interpretations of his data. In other words: Müttrich himself showed the scope of very different conclusions that could be drawn from his research project and the collected data. In contrast, Engler only presented doubts about his results in his spoken presentation at the IUFRO meeting, while the written report, as well as Flury's article in the Schweizerische

\footnotetext{
${ }^{48}$ L. W.: Union internationale des stations de recherches, Assemblée de 1906; in: Bulletin de la Société centrale forestière de Belgique 13 (1906), pp. 184-185.

${ }_{49}$ Myhrvold, Albert Karsten: Forstlig fors $\varnothing$ ksvæsen; in: Tidsskrift for Skovbrug 20 (1912), pp. 317-326.

${ }^{50}$ Flury: Die V. Versammlung, p. 26.

51 Schwappach, Adam: V. Versammlung des internationalen Verbandes forstlicher Versuchsanstalten in Württemberg; in: Zeitschrift für Forst- und Jagdwesen 36 (1906), pp. 811-817, here pp. 812-814; FAE Nr. 286, fol. 169-174, Adam Schwappach: Bericht über die Versammlung des internationalen Verbandes forstlicher Versuchsanstalten, 27 October 1906.

52 Janka, Gabriel: Fünfte Versammlung des Internationalen Verbandes forstlicher Versuchsanstalten in Württemberg 1906; in: Centralblatt für das gesammte Forstwesen 33 (1907), pp. 29-44, 72-86, 117-129, here p. 35f.

53 Archiv der Eidgenössischen Anstalt für das forstliche Versuchswesen, Zürich (EAFV), 1888/14, Bühler to Kappeler, 3 March 1888; EAFV 1906/3, 15 March 1906, Gnehm to members of the commission.
} 
Zeitschrift, draws clear conclusions. The Schweizerische Zeitschrift, as shown above, reported Engler's results that allowed for definite conclusions, whereas the German and Austrian journals stressed that the results were only preliminary and that further research had to be undertaken in order to get a reliable outcome.

On first impressions, the report in the Schweizerische Zeitschrift about clear results seem to back Pfister's and Brändli's thesis regarding a "paradigm" of deforestation in the mountains and higher risk of floods at rivers in the valleys. ${ }^{54}$ Obviously, Engler and Flury tried to support the efforts of Switzerland's forest administration to back the Swiss forest law forbidding deforestation in mountainous areas.

However, it would be a misunderstanding to characterize the Swiss report about the IUFRO as "politically" inspired, while also regarding the representations of the IUFRO in other forestry journals as "apolitical" or "independent" because they reported on unsolved questions. Rather, it is more fruitful to locate both kinds of representation into their respective contexts, taking into account the different centres ${ }^{55}$ that influenced these representations. Engler and Flury obviously operated within the Swiss context. Since the 1860 s, the debate about the creation and implementation of Swiss forest legislation created a sort of "gravitation centre", which influenced the representation of IUFRO research projects in a way whereby the results of these projects fitted into the Swiss context. The representation of IUFRO's work in the Prussian and Austrian contexts was aligned in relation to other centres: Adam Schwappach and the Prussian Forestry Academy in Eberswalde were major driving forces behind the foundation of the IUFRO in 1891/92. During the foundation procedure of the IUFRO, the Director of the Prussian Forestry Academy, Bernhard Danckelmann, explained in detail to the Prussian Minister of Agriculture the advantages of international cooperation in forest research. ${ }^{56}$ Here, the Ministry of Agriculture in Berlin formed the centre by which the representation was aligned. In order to ensure the Ministry's backing for the IUFRO, Danckelmann, and later Schwappach, reported continuously on the progress of the different research projects undertaken by IUFRO participants, while also stressing that the results of research projects were preliminary and required further investigation. ${ }^{57}$ Referring to unsolved scientific questions and necessary further research was the key aspect in the representation of the IUFRO' work in the Zeitschrift für Forst- und Jagdwesen. From the perspective of Danckelmann and Schwappach, such a representation was vital in order to validate the IUFRO' existence and emphasize the need for financial support from the Prussian Ministry.

\section{Conclusion and Perspectives for Further Research}

The representations of the IUFRO rain drain project differed remarkably in various European forestry journals. Participants of international research projects within the IUFRO took up selective aspects of these projects and created a representation of the IUFRO that fitted into specific national contexts. This case study on the IUFRO can be seen as a challenge for historical research on cross-border scientific exchanges in the early stages of cooperation of experts in international organizations during the late 19th century. Interestingly enough, the representation of the specific scientific work of international organizations in a scope of journals from different countries has not yet been studied systematically. Here, the article provided an example by which this particular approach to analysing the representation of international organizations in different journals was

\footnotetext{
54 Pfister/ Brändli: Rodungen im Gebirge.

55 Sivasundaram, Sujit: Sciences and the Global. On Methods, Questions, and Theory; in: Isis 101 (2010), pp. 146-158.

56 FAE Nr. 279, fol. 8, Danckelmann to Heyden, 18 October 1891.

57 For example FAE Nr. 286, fol. 169-174, Adam Schwappach: Bericht über die Versammlung des internationalen Verbandes forstlicher Versuchsanstalten, 27 October 1906.
} 
tested. The argument that deforestation in mountain areas would cause floods in the valleys achieved the quality of a discourse or even a paradigm in Switzerland by the end of the 19th century. However, in German and Austrian forestry journals, this discourse or paradigm was continuously questioned. It was obviously not the language that caused these differences, as main participants in the IUFRO (i.e., Swiss, Austrian and German forestry experts) chose German as their common language. Moreover, the working atmosphere within the IUFRO allowed for a coexistence of those different conclusions drawn from research projects, which did not endanger scientific cooperation. In contrast, the IUFRO seems to have been a sort of arena mediating these different interpretations and conclusions.

Based on this analysis of IUFRO's work and its different representations, this article finally suggests some perspectives for further research on international organizations dedicated to cross-border scientific cooperation. There is, for instance, intensive research on 19th century efforts to standardize the ways of collecting and arranging statistical data. Since the 1850s, participants of international statistical congresses and, later, the International Statistical Institute faced seemingly endless debates on suitable standards. ${ }^{58}$ Although Randeraad provides insights into the work of national delegates preparing their input to international statistical congresses, the representations of these congresses in journals have not been studied in detail. How did the different, maybe even opposing, representations of international statistical congresses influence the expectations of delegates from different countries? Such a question ought to focus on analysing the efforts of delegates to translate "international" debates to "national" audiences and vice versa. In addition, further research could explore how these delegates negotiated their role as either "international" or "national" scientists. ${ }^{59}$ Beyond the international statistical congresses, there is a wide variety of other congresses and organizations dealing with issues that caused similar problems. One area that might be suitable for further investigations concerns the international efforts towards the exploration and mapping of resources, energy capacity and use, and medical and hygienic conditions, as well as the standardization of the means of transport and communication etc. As this case study on the IUFRO has shown, the analysis of different journals from various countries allows for a clearer specification of the range and limits of scientific discourses, or even paradigms, in different countries or towards particular audiences.

\section{References}

\section{Archival sources}

Swiss Federal Institute for Forest, Snow and Landscape Research, Zurich/Switzerland, Archiv der Eidgenössischen Anstalt für das forstliche Versuchswesen (EAFV), 1888/14 and 1906/3.

University for Sustainable Development, Eberswalde/Germany, Archiv der königlich preußischen Forstakademie (FAE), 279 and 286.

National Archives Oslo/Norway, Riksarkiv, S-1600/ Dc/ D/ L2333.

\section{Published Material}

Administrativ-statistischer Atlas vom Preussischen Staate. (1827). Berlin. [Reprint with an introduction by Wolfgang Scharfe, Berlin 1990].

\footnotetext{
${ }^{58}$ Randeraad, Nico: The International Statistical Congress (1853-1876). Knowledge Transfers and their Limits; in: European History Quarterly 41 (2011), pp. 50-65.

59 As parts of the Archive in Eberswalde, including personal files of the IUFRO participants, were destroyed in 1945, it would be complicated to address this question to pre-1945 IUFRO. However, the example of Helen M. Rozwadowksi's work on ICES shows how fruitful this question is for the understanding of other international organizations (Rozwadowksi: The Sea Knows no Boundaries).
} 
Andréassian, V. (2004). Waters and forests: From historical controversy to scientific debate. Journal of Hydrology, 291(1-2), $1-27$.

Richard, A. (1890). Allgemeiner Handatlas, Bielefeld/Leipzig.

Anonymous. (1874). [Aleksej Sergeevič Ermolov?]: Sel'skohozâjstvennyj i lesnoj kongres" v Vene po voprosu o lesnoj statistike. Lesnoj Žurnal", 4, 115-120.

Anonymous. (1890). [probably Adolf von Liebenberg]: Der land- und forstwirthschaftliche Congress zu Wien 1890. Centralblatt für das gesammte Forstwesen, 16, 515-553.

Anonymous. (1873). Verhandlungen des internationalen Kongresses der Land- und Forstwirthe in Wien. Allgemeine Forst- und Jagdzeitung, 49, 401-411.

Ash, M. G. (2012). The nationalization of scientific knowledge in nineteenth-century Central Europe. In M. G. Ash and J. Surmann (eds.), The nationalization of scientific knowledge in the Habsburg Empire, 1848-1918. Basingstoke, 1-29.

Brzozowski, S. (1967). Studia rolnicze, leśne i weterynaryjne Polaków w Wiedniu od XVIII do XX w. Wrocław.

Cassidy, A., Lock, S. J., \& Voss, G. (2016). Sexual Nature? (Re)presenting Sexuality and Science in the Museum. Science as Culture, 25(2), 214-238.

Chlumecky, J. von. (1874). Stenographische Protokolle des ersten Internationalen Congresses der Land- und Forstwirthe (19. bis 24. September 1873) Wien 1874.

Congrès international de l'agriculture, 11-19 juin 1878, Paris 1879.

Demontzey, P. (1890). La correction des torrents et le reboisement des montagnes (Rapport présenté au Congrès de l'Exposition internationale de Vienne). Revue des eaux et forêts, 29, 485-502.

Faehndrich, J., \& Perthus, S. (2013). Visualizing the map-making process: Studying 19th century Holy Land cartography with MapAnalyst. E-Perimetron, 8(2), 60-84.

Fedotova, A., \& Loskutova, M. (2014). The studies over the impact of forests on climate and the rise of scientific forestry in Russia. From local knowledge and natural history to modern experiments in life sciences, 1840s-early 1890s. In Sharon K. \& Denise P. (eds.), Life sciences, agriculture and the environment. New York, 113-137.

Flury, P. (1907). Die V. Versammlung des Internationalen Verbandes forstlicher Versuchsanstalten in Württemberg vom 8.-16. September 1906. Schweizerische Zeitschrift für Forstwesen, 58, 25-27.

Foucault, M. (2002). Archaeology of Knowledge. London (fr.: L'archéologie du savoir, 1969).

Foucault, M. (1975). Discipline and Punish. The Birth of the Prison. London (fr.: Surveiller et punir, 1975).

Fryjordet, T. (1962). Skogadministrasjonen i Norge gjennom tidene, vol. 2: Tiden etter 1857, Oslo.

Grove, R. (1989). Scottish Missionaries, evangelical discourses and the origin of conservation thinking in Southern Africa 1820-1900. Journal of Southern African Studies, 15, 163-187.

Hartig, G. L. (1804). Anweisung zur Taxation und Beschreibung der Forste, 2., ganz umgearbeitete und stark vermehrte Auflage, Gießen/ Darmstadt.

Hölzl, R. (2016). Der "deutsche Wald" als Objekt eines transnationalen Wissenstranfers? Forstreform in Deutschland im 18. und 19. Jahrhundert; online: www.perspectivia.net/content/publikationen/discussions/7-2012/hoelzl_wald [4 December 2016].

Hölzl, R. (2010). Historicizing sustainability: German scientific forestry in the Eighteenth and Nineteenth centuries. Science as Culture, 24, 431-460.

Janka, G. (1907). Fünfte Versammlung des Internationalen Verbandes forstlicher Versuchsanstalten in Württemberg 1906. Centralblatt für das gesammte Forstwesen, 33, 29-44, 72-86, 117-129.

L. W. (1906). Union internationale des stations de recherches, Assemblée de 1906. Bulletin de la Société centrale forestière de Belgique, 13, 184-185.

Laak, D. van (2008). Planung. Geschichte und Gegenwart des Vorgriffs auf die Zukunft. Geschichte und Gesellschaft, 34, 305-326.

Lotz, C. (2015) Expanding the space for future resource management. Explorations of the timber frontier in Northern Europe and the rescaling of sustainability during the 19th century. Environment and History, 21, 257-279.

Lotz, C. (2016). Nachhaltige Herausforderung. Internationale forstwissenschaftliche Kongresse und die Maßstäbe zukünftiger Ressourcennutzung, ca. 1870-1914. In Turkowska, J. A., Haslinger, P., \& Schweiger, A. (eds.), Wissen transnational. Funktionen - Praktiken - Repräsentationen. Marburg, 223-242.

Lüdecke, C. (2002). Das Erste Internationale Polarjahr (1882-1883) und die Gründung der Deutschen Meteorologischen Gesellschaft im Jahr 1883. Historisch-meereskundliches Jahrbuch, 9, 7-24.

Mathieu, A. (1873). Congrès International Agricole et Forestier de Vienne en 1873. Revue des eaux et forêts, 12, 413-420. 
Müttrich, A. (1875/76). Beobachtungs-Ergebnisse der im Königreich Preussen und in den Reichslanden eingerichteten forstlich-meteorologischen Stationen, 2 vol., Berlin.

Müttrich, A. (1903). Bericht über die Untersuchung der Einwirkung des Waldes auf die Menge der Niederschläge. Für die vierte Versammlung des internationalen Verbandes forstlicher Versuchsanstalten zu Mariabrunn 1903, Neudamm.

Müttrich, A. (1892). Über den Einfluß des Waldes auf die Größe der atmosphärischen Niederschläge. Zeitschrift für Forst- und Jagdwesen, 24, 27-42.

Myhrvold, A. K. (1912). Forstlig forsøksvæsen. Tidsskrift for Skovbrug, 20, 317-326.

Pearson, A., Taylor, D. R., Kline, K. D., \& Heffernan, M. (2006). Cartographic ideals and geopolitical realities: International maps of the world from the 1890s to the present. Canadian Geographer, 50, 149-176.

Petrini, S. (1938). International cooperation in forestry. Svenska Skogsvårdsföreningens Tidskrift, 36, 1-28.

Pfister, C., \& Brändli, D. (1999). Rodungen im Gebirge - Überschwemmungen im Vorland. Ein Deutungsmuster macht Karriere. In Sieferle, R. P. \& Breuninger, H. (eds.), Natur-Bilder. Wahrnehmungen von Natur und Umwelt in der Geschichte. Frankfurt am Main/ New York, 297-324.

Proskowetz, Max von (ed.). (1890). Bericht über die Verhandlungen und Beschlüsse des internationalen land- und forstwirthschaftlichen Congresses/ Rapport sur les travaux et les résolutions du congrès international agricole et forestier, Wien.

Rackham, O. (1990). Trees and Woodland in the British Landscape. The Complete History of Britain's Trees, Woods and Hedgerows, London.

Radkau, J. (2011). Die Ära der Ökologie. Eine Weltgeschichte, München.

Radkau, J. (1986). Zur angeblichen Energiekrise im 18. Jahrhundert. Revisionistische Betrachtungen über die Holznot. Vierteljahrsschrift für Sozial- und Wirtschaftsgeschichte 73, 1-37.

Randeraad, N. (2011). The International Statistical Congress (1853-1876). Knowledge transfers and their limits. European History Quarterly, 41, 50-65.

Richter, A., \& Schwartz, E. (1967). Zur Gründung des internationalen Verbandes forstlicher Versuchsanstalten in Eberswalde 1892. Archiv für Forstwesen 16(6/9), 557-561.

Romer, E. (1901).Wpływ lasów na wody gruntowe i odpływ wód w rzekach. Sylwan, 19, 181-194.

Rozwadowski, H. M. (2002). The sea knows no boundaries. A century of marine science under ICES, Kopenhagen.

Schwappach, A. (1900). Dritte Versammlung des internationalen Verbandes forstlicher Versuchsanstalten. Zeitschrift für Forstund Jagdwesen, 32, 753-756.

Schwappach, A. (1906). V. Versammlung des internationalen Verbandes forstlicher Versuchsanstalten in Württemberg. Zeitschrift für Forst- und Jagdwesen, 36, 811-817.

Scott, J. C. (1998). Seeing like a state. How certain schemes to improve the human condition have failed. New Haven.

Scottish Arboricultural Society. (1884). International Forestry Exhibition 1884. Official Catalogue, Edinburgh.

Sivasundaram, S. (2010). Sciences and the global. On methods, questions, and theory. Isis 101, 146-158.

Somsen, G. J. (2008). A history of universalism. Conceptions of the internationality of science from the Enlightenment to the Cold War. Minerva, 46, 361-379.

Strangeways, I. (2010). A history of raingauges. Weather, 65(11), 133-138.

Weigl, E. (2004).Wald und Klima. Ein Mythos aus dem 19. Jahrhundert. Humboldt im Netz - Internationale Zeitschrift für Humboldt-Studien, 9, 80-99.

Wudowenz, R. (1992). 100 Jahre IUFRO [International Union of Forest Research Organizations]. Internationaler Verband Forstlicher Forschungsanstalten. Ausstellungen in der Alten Forstakademie Eberswalde, Eberswalde.

Żabko-Potopowicz, A. (1966). Wpływ zachodnioeuropejskiego piśmiennictwa i idei ekonomicznych na rozwój wczesnokapitalistycznego gospodarstwa leśnego w Królestwie Polskim. Studia z Dziejów Gospodarstwa Wiejskiego, 8, 311-320. 